\title{
CONTENTS OF BIORHEOLOGY, VOLUME 31, NUMBER 2
}

\author{
Contents
}

H. L. Goldsmith

M. Sato and N. Ohshima

M. Okano and Y. Yoshida

J. L. Williams, J. P. Iannotti, A. Ham, J. Bleuit and J. H. Chen

Y. Masuda, S. Kamisaka, R. Yamamoto,

T. Hoson and K. Nishinari

G. B. Thurston

L. H. Deng, J. C. Barbenel and G.D.O. Lowe

E. Friederichs and H.J. Meiselman iii Editorial

Papers

143 Flow-induced changes in shape and cytoskeletal structure of vascular endothelial cells

155 Junction complexes of endothelial cells in atherosclerosis-prone and atherosclerosis-resistant regions on flow dividers of brachiocephalic bifurcations in the rabbit aorta

163 Effects of fluid shear stress on bone cells

171 Changes in the rheological properties of the cell wall of plant seedlings under simulated microgravity conditions

179 Non-Newtonian viscosity of human blood: Flow-induced changes in microstructure

193 Influcnce of hematocrit on erythrocyte aggregation kinetics for suspensions of red blood cells in autologous plasma

207 Effects of calcium permeabilization on $\mathrm{RBC}$ rheologic behavior

217 Erratum

219 Contents of Clinical Hemorheology, Volume 13, Number 5 